\title{
"UTAUT EXTENSION MODEL: FAKTOR-FAKTOR PEMBENTUK BEHAVIORAL INTENTION TO REPURCHASE DALAM AKTIVITAS BELANJA ONLINE PADA MARKETPLACE C2C"
}

\author{
Andika Dzulhaji Pratama Putra \\ Sekolah Tinggi Manajemen PPM \\ andikadzpratama@gmail.com \\ Dr. Pepey Riawati Kurnia, MM \\ kurniapepey@gmail.com \\ Sekolah Tinggi Manajemen PPM
}

\begin{abstract}
ABSTRAK
Penelitian ini dimaksudkan untuk mengetahui faktor-faktor pembentuk niat untuk melakukan pembelian kembali seseorang pada layanan e-commerce. Penelitian ini merupakan jenis penelitian kuantitatif dengan total 206 responden yang terdiri dari pria \& wanita, dengan rentang usia 13-54 tahun yang berdomisili di Jakarta.

Kerangka konseptual dalam penelitian ini menggunakan model dasar UTAUT dengan melakukan modifikasi variabel yang telah banyak digunakan dalam penelitian sebelumnya dalam konteks aktivitas belanja online, seperti Penambahan variabel confirmation, trust, satisfaction dan perceived enjoyment. Modifikasi yang dilakukan diharapkan dapat meningkatkan faktor prediksi dalam pembelian kembali di marketplace.

Metode pengolahan data dalam penelitian ini menggunakan analisis structural equation model (SEM) dengan tools statistik AMOS. Pengujian pada AMOS menggunakan pengujian measurement model dan structural model. Pada pengujian measurement model merujuk pada pengujian validitas dan reliabilitas.

Hasil penelitian juga menunjukkan bahwa perceived expectancy dan perceived enjoyment merupakan faktor utama yang mempengaruhi seseorang untuk melakukan pembelian kembali pada aktivitas belanja online. Selain itu faktor trust terbukti mempengaruhi perceived usefulness dan faktor confirmation terbukti mempengaruhi perceived usefulness dan satisfaction.
\end{abstract}

Kata Kunci:

UTAUT extension, E-Commerce, Structural Equation Model, AMOS

\begin{abstract}
This research is to find out the factors of intention to repurchase someone on e-commerce services. This research is a quantitative research with a total of 206 respondents consisting of men \& women, with 13-54 years of age who are domiciled in Jakarta

The conceptual framework in this research using the basic UTAUT model by modifying variables that have been widely used in previous research in the context of online shopping activities such as the addition of confirmation, trust, satisfaction and perceived enjoyment variabel. Modifications made are expected to increase predictive factors in repurchasing in the marketplace.

The data processing method in this research using structural equation model (SEM) analysis with AMOS statistical tools. Analysis in AMOS using measurement models analysis and structural models analysis. In the measurement analysis refers to the testing of validity and reliability.

The results of this result show that perceived usefulness and perceived enjoyment are the main factors that influence someone to repurchase online shopping activities. In addition, factor trust is proven to affect perceived usefulness and confirmatory factors proven to affect perceived usefulness and satisfaction.
\end{abstract}

Key Words: UTAUT extension, E-Commerce, Structural Equation Model, AMOS 


\section{PENDAHULUAN}

Perkembangan teknologi dewasa ini sudah semakin pesat, kehadirannnya memberikan pengaruh besar dalam banyak aspek kehidupan, baik secara individu maupun industri. Kehadiran teknologi saat ini juga telah banyak mengubah pola kehidupan. Di masyarakat, teknologi membentuk tren baru yaitu tren perilaku masyarakat berbasis digital, di mana hampir keseluruhan aktivitas masyarakat dilakukan secara digital. Sedangkan bagi industri, kehadiran teknologi menuntut perusahaan harus dapat mengubah model bisnis mengikuti perilaku masyarakat yang mulai berbasis digital.

Salah satu dampak perkembangan teknologi yang dapat dilihat adalah lahirnya pasar electronic commerce (e-commerce) dan pertumbuhannya yang cepat. Menurut Indonesian E-Commerce Association (idEA), Indonesia merupakan negara dengan pertumbuhan e-commerce tertinggi di dunia. Selain itu, data sensus Badan Pusat Statistik juga menunjukkan bahwa pertumbuhan e-commerce dalam sepuluh tahun terakhir sebesar $17 \%$ dari total jumlah usaha e-commerce di Indonesia pada 2016 sebanyak 26.2 juta unit (liputan6, 2017).

Pertumbuhan ini akan semakin pesat karena didukung oleh pertumbuhan pengguna internet di Indonesia yang juga semakin tinggi. Hingga akhir 2017, menurut laporan APJII tahun 2017, dari total populasi penduduk Indonesia yang mencapai 262 juta orang, sebesar $54.68 \%$ atau sekitar 143.26 juta jiwa merupakan pengguna internet. Angka ini lebih meningkat sebesar 8\% dari tahun 2016 yaitu sebesar 132.7 juta jiwa.

Selain itu, dampak lain dari perkembangan pesat teknologi dalam laporan Mckinsey (2018) yang berujudul "How online commerce is driving Indonesia's economic development" adalah pada tahun 2022 kehadiran online commerce dapat meningkatkan pertumbuhan ekonomi Indonesia sebesar US\$ 65 miliar atau sekitar Rp 910 triliun. Hal ini juga didukung oleh penetrasi pengguna smartphone, tingkat adopsi masyarakat yang cepat dan juga peningkatan daya beli masyarakat.

Kehadiran e-commerce menjadi hal yang unik. Menurut Kenneth \& Carol (2011) salah satu karakteristik e-commerce adalah ubility, yang didefinisikan sebagai ketersediaan di mana dan kapan saja untuk digunakan. E-commerce menggeser cara kerja tradisional pasar yang 
menggandalkan marketplace. Dalam beberapa teori terkait e-commerce menunjukkan bahwa e-commerce merujuk pada aktivitas dalam melakukan transaksi penjualan dan pembelian secara online. Jika dilihat dari hubungan antar pasar di Indonesia, sebagian besar e-commerce merupakan e-commerce yang menujukkan aktivitas penjualan terbesar dilakukan antar individu dengan individu lainnya dan $e$ commerce Indonesia telah diintegrasikan dengan teknologi yang ada di smartphone sehingga secara pemanfaatan dapat disebut dengan aplikasi mobile commerce.

Di Indonesia, kehadiran e-commerce sangat pesat. Hasil survey Iprice Insight pada tahun 2018 mencatat sebanyak 45 pemain besar e-commerce di Indonesia. Jika dilihat berdasarkan jumlah pengunjung website marketplace di Indonesia, jumlah pengunjung website terbesar yaitu pada marketplace Tokopedia, Bukalapak, Shopee dan Jakmall.

Berdasarkan jumlah pengunjung (visitor) pada Q3 2018, Tokopedia berada di urutan pertama dengan total visitor website sebanyak 153.639 .700 visitor per bulan, Bukalapak sebanyak 95.932.100 visitor per bulan, Shopee sebanyak 38.882.000 visitor per bulan dan Jakmall sebanyak 1.318.400 per bulan. Iprice Insight (2018) juga melakukan kategori $\mathrm{C} 2 \mathrm{C}$ dengan merujuk pada penjualan produk yang dilakukan oleh seseorang baik itu produk yang dihasilkan sendiri maupun produk dari suatu merek tertentu. Hal ini sejalan dengan definisi yang dikemukakan oleh Turban, Lee, Turban, King, \& Liang (2015).

Selain itu, dilihat dari aspek pertumbuhan nilai transaksi aktivitas e-commerce Indonesia, nilai transaksi dalam aktivitas e-commerce ritel Indonesia akan tumbuh sebesar $86 \%$ menjadi US\$ 16.5 miliar atau sekitar Rp 219 triliun pada tahun 2022 dari posisi tahun 2017 sebesar US\$ 8.6 miliar atau sekitar Rp 118 triliun. Hal ini meningkat sejalan dengan pertumbuhan golongan kelas menengah di Indonesia yang juga terus meningkat (katadata, 2018).

Model popular terbaru yang banyak digunakan dalam memprediksi niat berprilaku dalam menggunakan teknologi baru adalah Unified Theory of Acceptance and Use of Technology (UTAUT) yang dibuat oleh Venkatesh et al, (2003) yang telah diuji dan diterapkan secara empiris dalam kondisi yang berbeda. Model UTAUT diyakini lebih kuat dari model penerimaan teknologi lainnya dalam 
mengevaluasi dan memprediksi penerimaan

teknologi. Variabel utama yang digunakan

pada model UTAUT dalam memprediksi

faktor-faktor yang mempengaruhi niat

mengadopsi layanan suatu teknologi yaitu

variabel performance expectancy, effort

expectancy, social influence, facilitating

condition, behavioral intention, dan use

behavior.

Terdapat beberapa penelitian yang menggunakan variabel dalam model UTAUT sebagai variabel penelitian dalam konteks teknologi yang berbeda-beda. Hal ini karena variabel dalam model UTAUT mampu menunjukkan $70 \%$ faktor-faktor dalam memprediksi niat seseorang terhadap penggunaan teknologi (Viswanath, Michael, \& Gordon, 2003).

Selain variabel-variabel utama dalam model UTAUT, beberapa penelitian lainnya melakukan modifikasi untuk menguji implementasi model UTAUT dalam konteks adopsi teknologi yang berbeda. Penelitian yang dilakukan oleh David (2000) dalam memprediksi faktorfaktor yang membuat seseorang mau melakukan transaksi melalui e-commerce, menggunakan variabel kepercayaan (trust) sebagai variabel mediator yang dapat membuat seseorang memutuskan untuk melakukan transaksi melalui e-commerce.

Penelitian lain yang dilakukan oleh Dewi, Hidayanto, Shihab, \& Zhu (2017) untuk mengetahui dampak kepercayaan terhadap penggunaan berkelanjutan layanan mobile untuk e-marketplaces $\mathrm{B} 2 \mathrm{C}$ menunjukkan bahwa trust memiliki pengaruh positif dalam membentuk niat seseorang untuk terus menggunakan layanan mobile untuk e-marketplace B2C. Hal ini menunjukkan bahwa trust menjadi faktor penting yang dapat mempengaruhi seseorang untuk menggunakan layanan $e$-commerce.

Aspek psikologis yang dirasakan berupa persepsi rasa senang/kesenangan (perceived enjoyment) ketika menggunakan suatu produk juga menjadi faktor yang dapat membuat seseorang mau menggunakan produk tersebut di masa yang akan datang. Kesenangan seseorang ketika menggunakan suatu layanan akan memunculkan rasa nyaman. Dan sebagai akibatnya, seseorang akan terus menggunakan layanan tersebut sepanjang itu dapat memenuhi kebutuhan mereka (Selim, Aren, Guzel, Kabadayi, \& Alpkan, 2013).

Penelitian yang dilakukan oleh Chao, Victor, \& Chenyan (2011) untuk memprediksi 
niat pembelian kembali konsumen online dalam aktivitas e-commerce menggunakan variabel dasar UTAUT yaitu perceived ease of use, perceived usefulness dan online repurchase intention dengan menambahkan variabel trust, confirmation dan satisfaction, menunjukkan bahwa variabel kepercayaan (trust), konfirmasi (confirmation) dan kepuasan (satisfaction) menjadi faktor-faktor yang membentuk niat seseorang untuk melakukan pembelian kembali dalam aktivitas e-commerce. Penelitian Dewi, Hidayanto, Shihab, \& Zhu (2017) menunjukkan bahwa fungsional sites website merupakan fokus utama konsumen online dalam melakukan transaksi secara online.

Konfirmasi menjadi sebuah keyakinan kognitif seseorang yang timbul karena pemenuhan ekspetasi yang telah dirasakan dalam penggunaan sebelumnya (Chao, Victor, \& Chenyan, 2011). Ekspetasi yang terpenuhi dari layanan akan menciptakan kepuasan. Hal ini sangat erat kaitannya dengan proses evaluasi yang akan berdampak pada penggunaan selanjutnya .Penelitian yang dilakukan oleh David (2000) juga menggunakan variabel kontak psikologis yaitu keakraban (familiarity) sebagai sebuah pemahaman terhadap suatu objek yang dirasakan dari interaksi sebelumnya. Hal ini merujuk pada hasil dari familiarity yang positif sehingga dapat memberikan pengalaman positif bagi pengguna dan akan berdampak pada penggunaan selanjutnya. Hal ini mengkonfirmasi penelitian yang dilakukan oleh Chao, Victor, \& Chenyan (2011) terhadap variabel konfirmasi (confirmation) sebagai hasil dari pengalaman positif yang dirasakan yang akan menjadi evaluasi konsumen online untuk penggunaan selanjutnya.

Untuk itu dalam penelitian ini, peneliti melakukan ekstensi terhadap model dasar UTAUT dengan harapan ekstensi model UTAUT dapat meningkatkan faktor prediktif terhadap penggunaan marketplace di Indonesia. Selain itu, fokus penelitian ini adalah aktivitas pembelian kembali, karena menurut data Cermati.com (2016) semakin tingginya persaingan pada masing-masing marketplace yang ada di Indonesia, membuat pelaku belanja online sangat mudah beralih. Niat untuk melakukan pembelian kembali (repurchase intention) juga merujuk pada penelitian yang telah dilakukan oleh Chao, Victor, \& Chenyan (2011) yang menunjukkan bahwa pengalaman yang telah dirasakan 
sebelumnya dapat mempengaruhi niat seseorang untuk kembali melakukan belanja pada platform yang ada.

\section{TINJAUAN TEORI DAN}

\section{PENGEMBANGAN HIPOTESIS}

\section{Electronic Commerce (E-Commerce)}

Secara umum e-commerce dapat dikatakan murni atau sebagian tergantung pada sifak aktivitas utamanya yaitu; pemesanan, pembayaran, pemenuhan pesanan dan pengiriman ke pelanggan, baik aktivitas dalam bentuk fisik maupun digital (Efraim, David, Jae Kyu, Ting-Peng, \& Deborrah, 2015).

Electronic Market dapat juga dilakukan pada pasar elektronik atau electronic market (e-marketplace). Dalam buku karya Efraim, David, Jae Kyu, TingPeng, \& Deborrah (2015) menyatakan bahwa e-marketplace merupakan lokasi atau tempat online di mana pembeli dan penjual melakukan transaksi komersial seperti menjual barang, layanan dan informasi. Setiap orang dalam emarkektplace dapat membuka pasar untuk menjual produk dan layanan mereka secara online. E-marketplace menghubungkan antara penjual dan pembeli melalui internet.

E-commerce menjadi teknologi yang sangat disarankan untuk melakukan aktivitas pemasaran dan penjualan. Dalam buku lain yang berjudul " $e$ commerce" karya Jeffrey \& Jaworski (2001), ecommerce didfinisikan sebagai teknologi yang memfasilitasi transaksi antara beberapa pihak (individual, organisasi atau keduanya).

\section{Performance Expectancy (PE)}

Performance expectancy merupakan sejauh mana seseorang percaya bahwa menggunakan sistem tertentu akan meningkatkan kinerja mereka. Konstruksi yang sama dalam model sebelumnya terkait performance expectancy yaitu perceived usefulness (TAM/TAM2 dan combined TAM-TPB), extrinsic motivation (MM), job fit (MPCU), relative advantage (DOI), dan outcome expectancy (SCT) (Viswanath, Michael, \& Gordon, 2003).

Effort Expectancy (EE)

Effort expectancy didefinisikan sebagai tingkat kemudahan yang berkaitan dengan penggunaan suatu sistem. Beberapa konstruksi yang sama dalam beberapa model sebelumnya yaitu perceived ease of use (TAM/TAM2), complexity (MPCU) dan ease of use (IDT) (Viswanath, Michael, \& Gordon, 2003). 
Social Influence (SI)

Social influence adalah sejauh mana eorang individu merasakan bahwa orang lain penting untuk percaya dalam menggunakan sistem baru. Konstruksi yang sama terkait social influence yaitu subjective norms (TRA, TAM2, TPB/DTPB, dan combined TAM-TPB), social factors (MPCU), dan image (DOI) (Viswanath, Michael, \& Gordon, 2003).

\section{Facilitating Condition (FC)}

Facilitating Condition didefinisikan sebagai sejauh mana seseorang percaya bahwa infrastruktur dan teknis yang ada telah mendukung penggunaan sistem. Beberapa konstruk yang sama dengan facilitating condition yaitu perceived behavioral control (TPB/DTPB, combined TAM-TPB), facilitating condition (MPCU) dan compability (IDT) (Viswanath, Michael, \& Gordon, 2003).

\section{Confirmation $(\mathbf{C})$}

Confirmation didefinisikan sebagai sebuah keyakinan kognitif tentang sejauh mana ekspektasi pengguna layanan terpenuhi di masa lalu sehingga menjadi bahan evaluasi untuk penggunaan selanjutnya (Chao, Victor, \& Chenyan, 2011).

\section{Satisfaction (S)}

Satisfaction didefinisikan sebagai kondisi psikologis seseorang yang dihasilkan dari harapan terhadap pengalaman yang dirasakan (Chao, Victor, \& Chenyan, 2011). Selain itu, Holmes, 1991 dalam penelitian Yulin, et al., (2014) mendefinisikan satisfaction sebagai hasil pertukaran evaluatif berdasarkan pengalaman yang dirasakan saat ini terhadap pengalaman masa lalu yang serupa dan saling berpengaruh.

Trust (T)

Menurut Beldad, Jong, dan Steehouder, 2010 dalam penelitian Tiago dan Matilde (2017) trust merupakan sebuah sikap dan tingkat kepercayaan seseorang terhadap sebuah situasi terhadap resiko kegiatan online yang rentan terhadap eksploitasi. Selain itu pendapat lain terkait dengan kepercayaan, yaitu Menurut Grandison \& Sloman, 2000 dalam Awuah (2012) yang mendefinisikan trust sebagai keyakinan dalam kompetensi suatu entitas untuk bertindak secara aman dan terpercaya dalam konteks tertentu. Selain itu menurut Rousseau et al., (1998) dalam Norizan (2010), kepercayaan merupakan sebuah keadaan psikologis yang dapat 


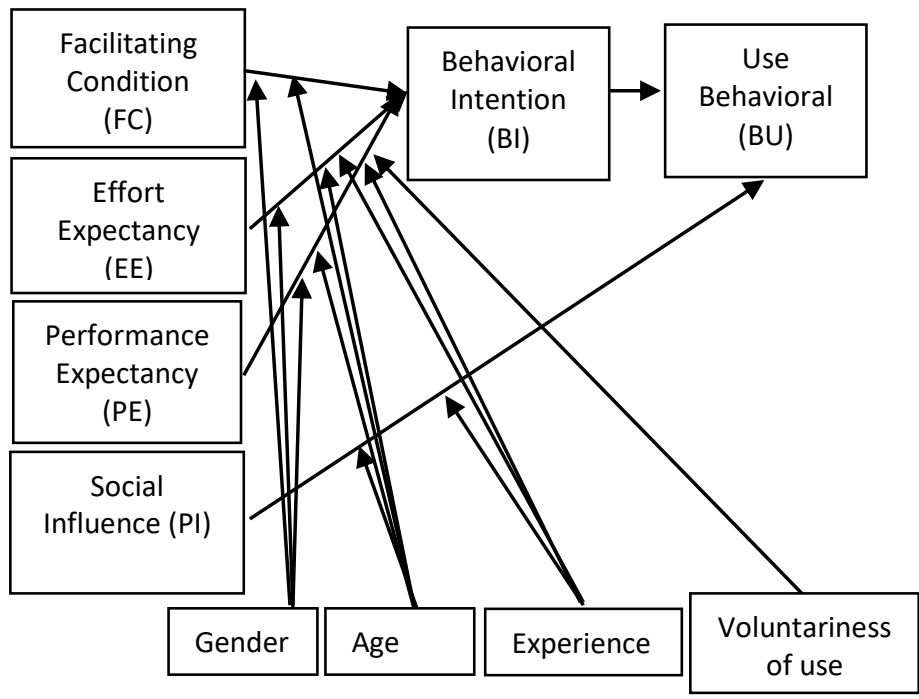

Gambar 1 The Unified Theory of Acceptance Use of Technology

Sumber: Viswanath, Michael, \& Gordon, 2003

mempengaruhi niat untuk menerima kerentanan atau resiko dari suatu aktivitas tertentu.

\section{Perceived Enjoyment (PEY)}

Menurut Chao, Victor, \& Chenyan (2011) enjoyment didefinisikan sebagai sebuah kesadaran holistik seseorang ketika benar-benar terlibat dalam aktivitas tertentu. Kesenangan yang dirasakan seseorang dalam melakukan belanja online sama pentingnya dengan kesenangan yang dirasakan saat melakukan belanja fisik dan hal ini memiliki pengaruh kuat terhadap niat dan perilaku pelanggan.

Behavioral Intention to Repurchase (BIR)

Behavioral Intention to Repurchase merupakan konstruk yang mengggabungkan antara teori information system atau IT intention dengan teori pemasaran (Chao, Victor, \& Chenyan, 2011). Dalam penelitian tersebut, variabel behavioral intention to repurchase menjadi variabel endogen untuk melihat seberapa besar niat seseorang untuk melakukan pembelian kembali secara online. Hal ini merujuk pada konstruksi behavioral intention dalam theory reasoned action.

\section{Teori untuk memprediksi niat dan perilaku}

\section{dalam adopsi teknologi}

Secara umum, terdapat beberapa teori yang digunakan dalam penelitian untuk memprediksi niat dan perilaku dalam penerimaan teknologi. Salah satu model yang paling banyak digunakan dan masih terus dikembangkan dalam penelitian saat ini yaitu model Unified Theory of Acceptance and Use of Technology (UTAUT) yang dibuat oleh Venkatesh et al, 2003.

Menurut Venkatesh et al, (2003) dalam Taiwo \& Downe (2013), model UTAUT diyakini lebih kuat dari model penerimaan teknologi lainnya dalam mengevaluasi dan memprediksi penerimaan teknologi. Model UTAUT menggunakan empat variabel utama untuk menentukan niat dan perilaku dalam mengadopsi teknologi, di antaranya; performance expectancy, 
effort expectancy, social influence, dan facilitating conditions.

Model UTAUT merupakan evolusi dari beberapa teori penerimaan teknologi yang sudah ada sebelumnya (Viswanath, Michael, \& Gordon, 2003). Variabel dalam model UTAUT diyakini telah dibentuk dari variabel valid yang diadopsi dari delapan model sebelumnya. Delapan model tersebut di antaranya; The Theory of reasoned action (TRA), The theory of Planned behavior (TPB), The technology acceptance model (TAM), The motivational Model (MM), A model combining the technology acceptance model and the theory of planned behavior (C-TAM-TPB), The model of PC Utilization (MPCU), The innovation diffusion theory (ID) dan Socio Cognitive Theory (SCT) (Taiwo \& Downe, 2013).

Konstruksi dalam model didefinisikan dan disesuaikan dengan variabel yang sama dalam delapan model yang telah ada sebelumnya. Sejak dipublikasi, UTAUT telah menjadi model dasar dan digunakan untuk mempelajari variasi penerimaan teknologi dalam aturan organisasi maupun non organisasi. Selain itu model UTAUT telah mampu menjelaskan $70 \%$ faktor dalam memprediksi niat perilaku dan $50 \%$ faktor terhadap penggunaan teknologi (Viswanath, Thong, \& Xu, 2012).

Konstruksi dalam model didefinisikan dan disesuaikan dengan variabel yang sama dalam delapan model yang telah ada sebelumnya. Sejak dipublikasi, UTAUT telah menjadi model dasar dan digunakan untuk mempelajari variasi penerimaan teknologi dalam aturan organisasi maupun non organisasi (Viswanath, Thong, \& $\mathrm{Xu}, 2012)$.

Model UTAUT telah diimplementasikan ke dalam beberapa konteks adopsi teknologi. Penelitian yang dilakukan oleh Samuel \& Hilla (2014) menunjukkan pemanfaatan model UTAUT pada teknologi yang berbeda-beda. Beberapa implementasi model UTAUT dalam penelitian di antaranya pada objek 3G mobile communication, banking, education dan health. Namun dalam penelitian lainnya yang menggunakan UTAUT sebagai dasar pengembangan konsep penelitian juga digunakan dalam konteks e-government. Dalam penelitian Suha \& Anne (2008), penelitian John \& Paul (2004) terhadap objek telecommunication, penelitian Erin \& Rajiv (2006) pada objek e-business, penelitian Abdul \& Steve (2012) pada e-commerce, penelitian Chian 


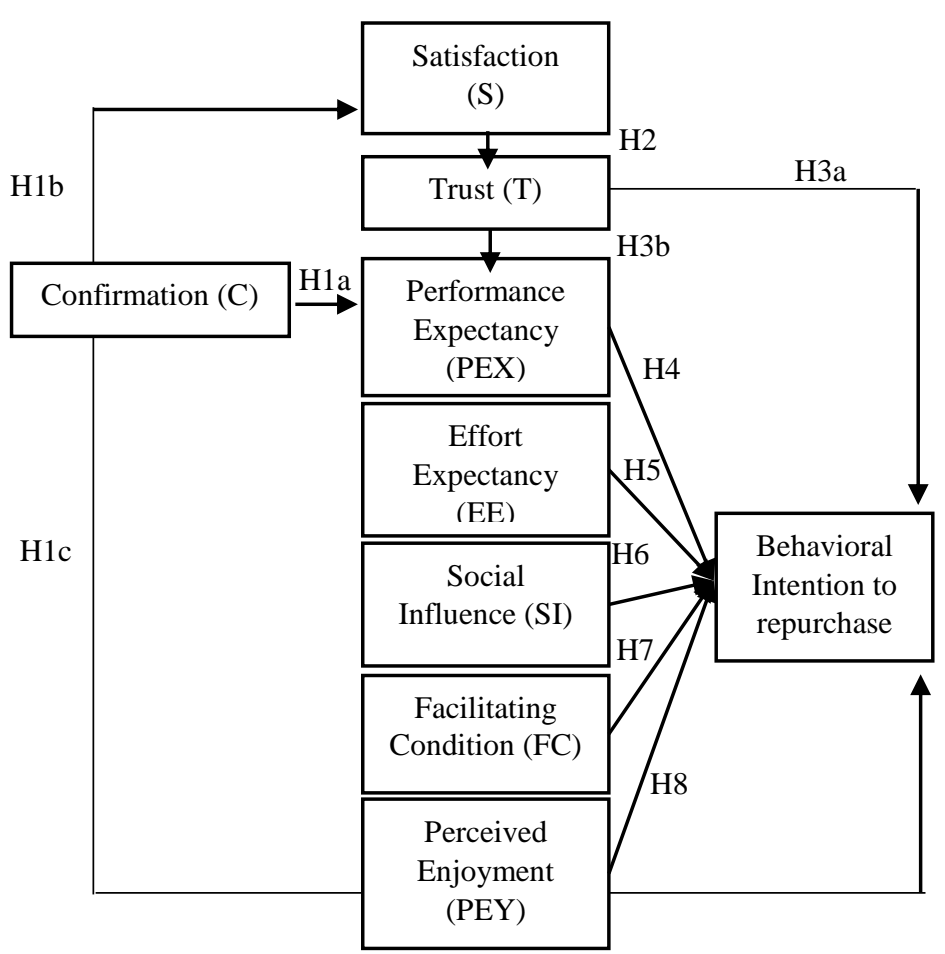

Gambar 2. Kerangka Konseptual

Penelitian

(2012) pada objek m-banking dan beberapa

konteks lainnya yang berbeda-beda.

Gambar 2 merupakan kerangka konseptual penelitian yang dikembangkan dari model dasar UTAUT. Fokus dalam penelitian ini untuk melihat faktor-faktor yang dapat membentuk niat seseorang untuk melakukan pembelian kembali secara online melalui marketplace. Selain itu niat untuk melakukan pembelian kembali (repurchase intention) juga merujuk pada penelitian yang telah dilakukan oleh Chao, Victor, \& Chenyan (2011) dengan hasil yang menunjukkan bahwa pengalaman yang telah dirasakan sebelumnya dapat mempengaruhi niat seseorang untuk kembali melakukan belanja pada platform yang ada.

\section{Hipotesis Penelitian}

Berdasarkan kerangka analisis, maka hipotesis dalam penelitian ini adalah:

1) Uji Hipotesis 1a : Terdapat pengaruh positif signifikan antara konfirmasi (confirmation) terhadap ekspektasi manfaat (performance expectancy) dalam aktivitas belanja online pada marketplace $\mathrm{C} 2 \mathrm{C}$

2) Uji Hipotesis $1 \mathrm{~b}:$ Terdapat pengaruh positif signifikan antara konfirmasi (confirmation) terhadap kepuasan (satisfaction) dalam aktivitas belanja online pada marketplace $\mathrm{C} 2 \mathrm{C}$

3) Uji Hipotesis 1c: Terdapat pengaruh positif signifikan antara konfirmasi (confirmation) terhadap niat untuk membeli kembali (behavioral intention to repurchase) dalam aktivitas belanja online pada marketplace $\mathrm{C} 2 \mathrm{C}$

4) Uji Hipotesis 2: Terdapat pengaruh positif signifikan antara kepuasan (satisfaction) terhadap kepercayaan (trust) dalam aktivitas belanja online pada marketplace $\mathrm{C} 2 \mathrm{C}$ 
5) Uji Hipotesis 3a : Terdapat pengaruh positif signifikan antara kepercayaan (trust) terhadap niat untuk membeli kembali (behavioral intention to repurchase) dalam aktivitas belanja online pada marketplace $\mathrm{C} 2 \mathrm{C}$

6) Uji Hipotesis 3b : Terdapat pengaruh positif signifikan antara kepercayaan (trust) terhadap ekspektasi kinerja (performance expectancy) dalam aktivitas belanja online pada marketplace $\mathrm{C} 2 \mathrm{C}$

7) Uji Hipotesis 4 : Terdapat pengaruh positif signifikan antara ekspektasi manfaat (performance expectancy) terhadap niat untuk membeli kembali (behavioral intention to repurchase) dalam aktivitas belanja online pada marketplace $\mathrm{C} 2 \mathrm{C}$

8) Uji Hipotesis 5 : Terdapat pengaruh positif signifikan antara ekspektasi kemudahan penggunaan (effort expectancy) terhadap niat untuk membeli kembali (behavioral intention to repurchase) dalam aktivitas belanja online pada marketplace $\mathrm{C} 2 \mathrm{C}$
9) Uji Hipotesis 6 : Terdapat pengaruh positif signifikan antara pengaruh sosial (social influence) terhadap niat untuk membeli kembali (behavioral intention to repurchase) dalam aktivitas belanja online pada marketplace $\mathrm{C} 2 \mathrm{C}$

10) Uji Hipotesis 7 : Terdapat pengaruh positif signifikan antara kondisi yang memfasilitasi (facilitating condition) terhadap niat untuk membeli kembali (behavioral intention to repurchase) dalam aktivitas belanja online pada marketplace $\mathrm{C} 2 \mathrm{C}$

11) Uji Hipotesis $8:$ Terdapat pengaruh positif signifikan antara persepsi kesenangan dalam menggunakan (perceived enjoyment) terhadap niat untuk membeli kembali (behavioral intention to repurchase) dalam aktivitas belanja online pada marketplace $\mathrm{C} 2 \mathrm{C}$

\section{METODE RISET}

Penelitian ini menggunakan metode structural equation model (SEM) dengan analisis covariance based SEM yang bersifat multiple regression analysis menggunakan program komputer AMOS. Menurut Singgih, 2012 SEM adalah teknik statistik multivariat yang 
merupakan kombinasi antara analisis faktor dan analisis regresi (korelasi), yang bertujuan untuk menguji hubunganhubungan antar variabel yang ada pada sebuah model, baik itu antara indikator dengan konstruknya, ataupun hubungan antar konstruk. Dalam analisis SEM dengan AMOS, terdapat dua pengujian model yaitu; 1) Uji measurement model dan 2) Uji structural model.

Pengujian measuremet model merupakan uji yang dilakukan untuk memastikan bahwa konstruk dalam variabel dapat diukur dan merupakan konstruk yang membentuk variabel tersebut. Indikator penilaian dalam uji measurement model menggunakan AMOS yaitu dengan melihat output standardized regression weight dengan kriteria: (a) Jika nilai estimate indikator dalam variabel >0,6, maka item valid, yang berarti indikator tersebut merupakan konstruk yang menyusun variabel yang diteliti; (b) Jika nilai estimate indikator dalam variabel $<0,6$, maka item tidak valid, yang berarti indikator tersebut bukan merupakan konstruk yang menyusun variabel yang diteliti.
Pengujian structural model, merupakan uji yang dilakukan untuk mengetahui tingkat validitas prediktif terhadap variabel-variabel yang diteliti. Uji ini juga dilakukan untuk melihat konstruk yang paling dominan dalam suatu hubungan dari pengembangan hipotesis yang dilakukan. Indikator-indikator penilaian dalam uji structural model lebih kompleks dibandingkan uji pada measurement model, namun dasar yang digunakan yaitu dengan melihat kesederhanaan model (goodness of fit), dengan indikator sebagai berikut.

a. Uji Absolute Fit Indices akan membandingkan secara langsung sampel dengan estimasi, dengan kriteria membandingkan nilai CMIN default model dengan CMIN saturated dan independent model pada output model fit summary AMOS. Jika nilai CMIN pada default model berada di antara nilai CMIN saturated dan independent model maka model dapat dianggap fit dan menunjukkan dukungan terhadap hasil dari Chi-Square. Dalam menguji hipotesis yaitu dengan melihat nilai estimate pada output regression weights, jika nilai probability > 0,05 maka $\mathrm{H}_{0}$ tidak ditolak, dan jika nilai probability $<0,05$ maka $\mathrm{H}_{0}$ ditolak. 
Tabel 1. Regression Weights

\begin{tabular}{|c|ccl|c|c|c|c|c|}
\hline Hipotesis & & & & Estimate & S.E. & C.R. & P & Keterangan \\
\hline H1a & PEX & $<-$ & $\mathrm{C}$ & .627 & .097 & 6.485 & $* * *$ & Positif Signifikan \\
H1b & $\mathrm{S}$ & $<-$ & $\mathrm{C}$ & .967 & .099 & 9.769 & $* * *$ & Positif Signifikan \\
$\mathrm{H} 1 \mathrm{c}$ & $\mathrm{BIR}$ & $<-$ & $\mathrm{C}$ & .474 & .248 & 1.909 & .056 & Tidak Berhubungan \\
$\mathrm{H} 2$ & $\mathrm{~T}$ & $<-$ & $\mathrm{S}$ & .947 & .133 & 7.134 & $* * *$ & Positif Signifikan \\
$\mathrm{H} 3 \mathrm{a}$ & $\mathrm{BIR}$ & $<-$ & $\mathrm{T}$ & -.069 & .038 & -1.822 & .068 & Tidak Berhubungan \\
$\mathrm{H} 3 \mathrm{~b}$ & $\mathrm{PEX}$ & $<-$ & $\mathrm{T}$ & .063 & .040 & 1.554 & .120 & Tidak Berhubungan \\
$\mathrm{H} 4$ & $\mathrm{BIR}$ & $<-$ & $\mathrm{PEX}$ & .294 & .145 & 2.024 & .043 & Positif Signifikan \\
$\mathrm{H} 5$ & $\mathrm{BIR}$ & $<-$ & $\mathrm{EE}$ & .073 & .122 & .598 & .550 & Tidak Berhubungan \\
$\mathrm{H} 6$ & $\mathrm{BIR}$ & $<-$ & $\mathrm{SI}$ & .095 & .077 & 1.239 & .215 & Tidak Berhubungan \\
$\mathrm{H} 7$ & $\mathrm{BIR}$ & $<-$ & $\mathrm{FC}$ & -.479 & .283 & -1.695 & .090 & Tidak Berhubungan \\
$\mathrm{H} 8$ & $\mathrm{BIR}$ & $<-$ & $\mathrm{PEY}$ & .458 & .165 & 2.773 & .006 & Positif Signifikan \\
\hline
\end{tabular}

b. Uji Incremental Fit Indices akan membandingkan model tertentu dengan null model yaitu model yang diasumsikan bahwa semua indikator tidak berkorelasi satu dengan lainnya, dengan kriteria: (1) Membandingkan nilai NFI (normed fit index), CFI (comparative fit index), IFI dan RFI. Jika semua nilai NFI, CFI, IFI, dan RFI >0,8 maka model dapat dianggap fit; (2) Membandingkan nilai GFI (goodness of fit index) dan AGFI (adjusted goodness of fit index). Jika nilai GFI dan AGFI $>0,8$, maka model dapat dianggap fit; (3) Membandingkan nilai RMSEA, Jika nilai RMSEA $<0,08$ maka model dapat dianggap fit.

\section{HASIL PENELITIAN DAN PEMBAHASAN}

\section{Uji Hipotesis}

Hasil pengujian measurement model dalam penelitian ini menunjukkan 29 item valid karena memiliki nilai standrized regression weights > 0,6. Sehingga dengan ini pengujian structural dapat dilakukan. Pengujian secara structural model menunjukkan bahwa nilai chi-square positif menunjukkan jumlah data terpenuhi, nilai probability $(\mathrm{P})<0,05$ menunjukkan model fit, 
nilai TLI 0,842 >0,8 menunjukkan model fit, nilai GFI $0,803>0,8$ menunjukkan model fit, nilai AGFI $0,752<0,8$ menunjukkan model mendekati fit, nilai CFI 0,888 > 0,8 menunjukkan model fit dan nilai RMSEA $0,079<0,08$ menunjukkan model fit. Dengan demikian, pengujian structural model II menunjukkan model telah fit.

Setelah mendapatkan model yang fit, maka selanjutnya dilakukan pengujian hipotesis penelitian. Pengujian hipotesis dilakukan dengan melihat nilai estimate pada output regression weights, jika nilai probability $>0,05$ maka $\mathrm{H}_{0}$ tidak ditolak, dan jika nilai probability $<0,05$ maka $\mathrm{H}_{0}$ ditolak. Pada output amos tanda “***” menunjukkan tingkat hubungan positif dan signifikan.

\section{Diskusi}

Responden dalam penelitian ini berjumlah 206 responden yang berdomisili di Jakarta dan didominasi oleh responden yang tinggal di Jakarta dan melakukan aktivitas belanja online pada marketplace yang ada di Indonesia di antaranya Tokopedia, Bukalapak, Shopee dan Jakmall. Mayoritas responden dalam penelitian ini didominasi oleh responden pria sebanyak $55 \%$ atau 113 responden dan $45 \%$ atau 93 responden lainnya merupakan responden wanita. Hal ini didukung oleh riset yang dilakukan oleh Priceprice.com pada tahun 2017 bahwa sebesar $68 \%$ aktivitas belanja online didominasi oleh kaum pria (CNBC Indonesia, 2018).

Mayoritas responden dalam penelitian ini berdomisili di wilayah Jakarta Timur dengan komposisi sebesar 33\% atau 67 responden. Jika ditinjau dari aspek usia, responden dalam penelitian ini didominasi oleh usia milennial yaitu 19-34 tahun sebanyak 91\% atau 188 responden, sebanyak 6\% atau 13 responden lainnya berusia 35-54 tahun dan 2\% lainnya atau 5 responden berusia 13-18 tahun. Hal ini sejalan juga dengan riset yang dilakukan oleh Priceprice.com (CNBC Indonesia, 2018) pada tahun 2017 yang menunjukkan bahwa aktivitas belanja online didominasi oleh pria dengan usia rentan 18-35 tahun dan masuk ke dalam kategori generasi millennial.

Selain itu, mayoritas pendidikan responden dalam penelitian ini yaitu memiliki pendidikan Strata-1 (S1) dengan komposisi sebesar 80,1\% atau 165 responden yang mayoritas telah bekerja sebagai pegawai swasta dengan rata-rata 
penghasilan Rp 5.000.001 - Rp 10.000.000 per bulan.

Dari aspek perilaku belanja online menunjukkan bahwa mayoritas responden melakukan aktivitas belanja online pada marketplace Tokopedia dengan komposisi sebesar 52\% atau 109 responden, dengan rata-rata melakukan belanja online sebanyak 2-3 kali per bulan. Selain itu ratarata alokasi dana responden dalam melakukan aktivitas belanja online yaitu $\mathrm{Rp}$ 300.001 - Rp 500.000 dengan pembayaran menggunakan metode pembayaran melalui m-banking.

Dalam penelitian ini terdapat 8 hipotesis yang akan dibuktikan. Hasil pengolahan data menunjukkan bahwa hipotesis 1a yaitu variabel pengalaman penggunaan sebelumnya (confirmation) berpengaruh signifikan terhadap harapan manfaat yang diterima (performance expectancy) dengan nilai $\mathrm{P} * * *<0,05$ sehingga $\mathrm{H} 1 \mathrm{a}$ diterima dan $\mathrm{H}_{0}$ ditolak. Variabel confirmation dapat diartikan bahwa responden yang memiliki pengalaman baik dalam melakukan aktivitas belanja online pada marketplace tertentu, membuat responden berharap mendapatkan manfaat lebih banyak pada aktivitas belanja online diwaktu yang akan datang. Hasil ini mendukung hipotesis pada penelitian yang dilakukan oleh Chao, Victor, \& Chenyan (2011) yang menunjukkan bahwa terdapat hubungan antara confirmation terhadap perceived usefulness.

Selain itu dalam penelitian Chao, Victor, \& Chenyan (2011) menunjukkan bahwa konfirmasi menjadi sebuah keyakinan kognitif seseorang yang timbul karena pemenuhan ekspetasi yang telah dirasakan dalam penggunaan sebelumnya. Ekspetasi yang terpenuhi dari layanan akan menciptakan kepuasan. Hal ini sangat erat kaitannya dengan proses evaluasi yang akan berdampak pada penggunaan selanjutnya. Hipotesis $1 \mathrm{~b}$ yaitu pengalaman penggunaan sebelumnya (confirmation) memiliki pengaruh yang signifikan terhadap kepuasan penggunaan (satisfaction) dengan nilai $\mathrm{P} * * *<0,05$ sehingga H1b diterima dan $\mathrm{H}_{0}$ ditolak, sehingga dapat diartikan bahwa responden yang memiliki pengalaman baik dalam melakukan aktivitas belanja online pada marketplace tertentu cenderung akan merasakan kepuasan, sehingga dapat berdampak pada keputusan untuk menggunakan di masa yang akan datang. Hasil ini mendukung hipotesis pada penelitian yang 
dilakukan oleh Chao, Victor, \& Chenyan

(2011) yang menunjukkan bahwa terdapat hubungan antara confirmation terhadap satisfaction. Sejalan dengan pengalaman positif yang dirasakan, ini tentunya akan memberikan kepuasan tersendiri bagi konsumen yang melakukan aktivitas belanja online, baik kepuasan dalam aktivitas belanja itu sendiri, kepuasan dalam melakukan komunikasi dengan penjual dalam suatu marketplace, kepuasan kualitas produk yang dijual hingga penyampaian keluhan terhadap barang atau layanan yang ada di marketplace tertentu.

Sesuai dengan hipotesis 1c pada penelitian ini terkait dengan pengalaman penggunaan sebelumnya (confirmation) mempengaruhi niat seseorang untuk memilih menggunakannya kembali (behavioral intention to repurchase) dengan nilai $\mathrm{P} 0,056>0,05$ sehingga $\mathrm{H} 1 \mathrm{c}$ tidak diterima dan $\mathrm{H}_{0}$ diterima. Bahwa seseorang yang memiliki pengalaman positif dalam melakukan aktivitas belanja online tidak mempengaruhi seseorang untuk mau kembali melakukan aktivitas berbelanja online pada marketplace sejenis dikemudian hari. Selain itu, Hipotesis 2 dalam penelitian ini yaitu kepuasan (satisfaction) mempengaruhi kepercayaan (trust) dengan nilai $\mathrm{P}$ *** $<0,05$ sehingga $\mathrm{H} 2$ diterima dan $\mathrm{H}_{0}$ ditolak. Hal ini sejalan dengan penelitian Chao, Victor, \& Chenyan (2011) yang menyatakan bahwa kepuasan merupakan suatu faktor sosial yang baik secara langsung maupun tidak langsung akan memberikan pengaruh terhadap keinginan konsumen untuk melakukan pembelian secara online. Adanya kepastian yang jelas sepanjang konsumen melakukan aktivitas belanja online secara tidak langsung akan memberikan kepuasan kepada penggunanya. Hal ini penting karena sejalan dengan penelitian Viswanath, James, \& Frank (2011) menyatakan bahwa kepercayaan dapat tercipta sebagai akibat dari berkurangnya ketidak pastian dalam penggunaan suatu sistem.

Hipotesis 3a yaitu kepercayaan (trust) mempengaruhi niat seseorang untuk memilih menggunakannya kembali (behavioral intention to repurchase) dengan nilai $\mathrm{P} 0,068>0,05$ sehingga $\mathrm{H}_{0}$ diterima dan $\mathrm{H} 3 \mathrm{a}$ ditolak. Angka tersebut menunjukkan bahwa tidak terdapat pengaruh signifikan antara kepercayaan seseorang dalam melakukan aktivitas online terhadap keputusan untuk menggunakannya kembali. Pada penelitian yang dilakukan oleh Chao, Victor, \& Chenyan (2011) terkait dengan model terintegrasi 
untuk pembelian kembali konsumen secara online menunjukkan tidak ada hubungan. Hal ini dapat disebabkan karena kepercayaan memang menjadi hambatan utama bagi konsumen online dalam melakukan aktivitas belanja secara online.

Hipotesis 3b yaitu yaitu kepercayaan (trust) berpengaruh signifikan terhadap harapan manfaat yang diterima (performance expectancy) dengan nilai $\mathrm{P}$ $0,120>0,05$ sehingga $\mathrm{H}_{0}$ diterima dan $\mathrm{H} 3 \mathrm{~b}$ ditolak. Dengan kata lain, tidak terdapat pengaruh antara kepercayaan seseorang dalam melakukan aktivitas online terhadap harapan manfaat dari berbelanja online pada marketplace tertentu. Hal ini dapat diterima karena dalam penelitian selanjutnya untuk Hipotesis 4 yaitu harapan manfaat yang diterima (performance expectancy) berpengaruh signifikan terhadap niat seseorang untuk memilih menggunakannya kembali (behavioral intention to repurchase) dengan nilai $\mathrm{P}$ $0,043<0,05$ sehingga $\mathrm{H} 4$ diterima dan $\mathrm{H}_{0}$ ditolak. Hasil ini menunjukkan bahwa pemenuhan ekspetasi terhadap manfaat yang didapatkan ketika melakukan aktivitas belanja online pada marketplace tertentu dapat membentuk niat seseorang untuk memilih marketplace tersebut sebagai tempat untuk melakukan aktivitas belanja online dikemudian hari. Ini sejalan dengan hasil penelitian yang dilakukan oleh Chao, Victor, \& Chenyan (2011) yang menunjukkan pengaruh signifikan antara perceived usefulness terhadap online repurchase intention seseorang ketika melakukan aktivitas belanja online .

Pada Hipotesis 5 penelitian ini yaitu kemudahan penggunaan (effort expectancy) berpengaruh signifikan terhadap niat seseorang untuk memilih menggunakan kembali (behavioral intention to repurchase) menunjukkan nilai $\mathrm{P}$ 0,550>0,05 sehingga $\mathrm{H}_{0}$ diterima dan $\mathrm{H} 5$ ditolak. Hal ini menunjukkan bahwa kemudahan melakukan belanja online pada marketplace tertentu tidak mempengaruhi niat seseorang untuk kembali berbelanja di marketplace tertentu. Pada penelitian yang dilakukan oleh Chao, Victor, \& Chenyan (2011), kemudahan penggunaan ease of use menjadi variabel anteseden variabel kepercayaan (trust) dan harapan terhadap manfaat (perceived usefulness) yang membentuk niat membeli kembali secara online (online repurchase intention). Variabel kemudahan penggunaan (effort expectancy) merupakan salah satu variabel kunci dalam model UTAUT dalam 
memprediksi faktor-faktor adopsi teknologi

seseorang. Kemudahan ini menjadi salah

satu variabel kunci karena pengguna

layanan baru pada umumnya akan

membutuhkan usaha yang lebih untuk

mempelajari penggunaan sistem tersebut.

Sehingga semakin mudah suatu sistem

digunakan maka kemungkinan adopsi

sistem dan penggunaan selanjutnya akan

semakin tinggi (Viswanath, Michael, \&

Gordon, 2003).

Hipotesis 6 dan 7 pada penelitian ini yaitu pengaruh sosial (social influence) dan kondisi yang terfasilitasi (facilitating condition) berpengaruh positif terhadap niat seseorang untuk memilih menggunakan kembali (behavioral intention to repurchase) menunjukkan nilai $\mathrm{P}$ social influence yaitu $0,215>0,05$ dan nilai $\mathrm{P}$ facilitating condition memiliki nilai $\mathrm{P}$ 0,090 > 0,05 yang berarti $\mathrm{H} 6$ dan $\mathrm{H} 7$ tidak diterima dan $\mathrm{H}_{0}$ diterima. Sehingga dapat diartikan bahwa social influence dan facilitating condition tidak berpengaruh terhadap niat seseorang untuk memilih kembali (behavioral intention to repurchase) marketpace tertentu untuk melakukan aktivitas belanja online.
Hipotesis 8 yaitu persepsi kenyamanan (perceived enjoyment) mempengaruhi niat seseorang untuk memilih menggunakan kembali (behavioral intention to repurchase) menunjukkan nilai $\mathrm{P} 0,006<0,05$ sehingga $\mathrm{H} 8$ diterima dan $\mathrm{H}_{0}$ ditolak, sehingga terdapat pengaruh positif dan signifikan antara persepsi kenyamanan terhadap niat seseorang untuk kembali melakukan aktivitas belanja online pada martketplace tertentu. Aspek kenyamanan ini dapat ditunjukkan dengan tampilan konten seperti warna, pemilihan kata dan bahasa serta kualitas gambar, terdapat deskirpsi produk yang jelas hingga ketersediaan promo dalam suatu marketplace. Hal ini sejalan dengan penelitian yang dilakukan Chao, Victor, \& Chenyan (2011) yang menunjukkan bahwa terdapat pengaruh positif dan signifikan antara perceived enjoyment terhadap behavioral intention to repurchase pada aktivitas belanja online seseorang.

\section{KESIMPULAN DAN SARAN}

\section{Kesimpulan}

Dari hasil penelitian yang dilakukan, maka dapat ditarik kesimpulan bahwa pengalaman penggunaan yang dirasakan sebelumnya (confirmation) memiliki pengaruh terhadap harapan manfaat yang didapatkan (performance 
expectancy) dan kepuasan yang dirasakan (satisfaction) dalam melakukan aktivitas belanja online pada suatu marketplace. Namun, pengalaman penggunaan yang dirasakan sebelumnya (confirmation) tidak memiliki pengaruh terhadap niat seseorang untuk melakukan kembali (behavioral intention to repurchase) aktivitas belanja online pada suatu marketplace.

Selain itu, variabel kepuasan yang dirasakan (satisfaction) berpengaruh terhadap kepercayaan (trust) seseorang. Penelitian ini juga menunjukkan bahwa kepercayaan (trust) berpengaruh terhadap harapan manfaat yang didapatkan (performance expectancy) sehingga akan mempengaruhi niat seseorang untuk memilih kembali (behavioral intention to repurchase). Sementara harapan kemudahan penggunaan yang dirasakan (effort expectancy) tidak berpengaruh terhadap niat seseorang untuk memilih kembali (behavioral intention to repurchase) pada marketplace yang dipilih untuk aktivitas belanja online.

Selain itu, uji sctructural model pada penelitian ini juga menunjukkan bahwa tidak terdapat pengaruh signifikan antara pengaruh sosial (social influence), kondisi yang difasilitasi (facilitating condition), terhadap niat seseorang untuk memilih kembali (behavioral intention to repurchase) pada marketplace yang dipilih untuk melakukan belanja online.

Sedangkan faktor persepsi kenyamanaan penggunaan (perceived enjoyment) memliki pengaruh terhadap niat seseorang untuk memilih kembali (behavioral intention to repurchase) melakukan belanja online di marketplace yang telah digunakan sebelumnya.

\section{Saran}

Penelitian ini menunjukkan bahwa pengalaman penggunaan yang sudah dirasakan sebelumnya (confirmation) dapat memberikan pengaruh kepada kepuasan (satisfaction) seseorang dalam melakukukan aktivitas belanja online. Oleh karena itu, penting bagi penyelenggara marketplace untuk memaksimalkan pengalaman konsumen (customer experience) dalam hal proses pembayaran konsumen terhadap suatu produk baik berupa barang maupun jasa, pengalaman konsumen dalam pemilihan produk, kualitas produk, maupun penanganan keluhan yang dialami oleh konsumen. Hal ini menjadi penting karena terpenuhinya manfaat yang diharapkan oleh konsumen memungkinkan konsumen 
melakukan pembelian kembali pada marketplace tersebut.

Penelitian ini juga menunjukkan bahwa pengalaman penggunaan yang sudah dirasakan sebelumnya (confirmation) berpengaruh terhadap ekspetasi manfaat yang dirasakan (performance expectancy) seseorang dalam melakukukan aktivitas belanja online, sehingga penyelenggara marketplace dapat memberikan manfaat kepada konsumen yang melakukan belanja pada marketplace tersebut. Beberapa manfaat yang diharapkan dapat dirasakan oleh konsumen ketika melakukan aktivitas belanja online yaitu manfaat waktu terhadap kecepatan dalam melakukan proses belanja itu sendiri, kemudahan dalam membuat keputusan pembelian karena banyaknya alternatif produk dan vendor yang berbeda yang menawarkan berbagai jenis produk dan harga yang bervariasi, manfaat secara financial karena beberapa aktivitas yang akan memerlukan biaya tidak lagi ada ketika seseorang melakukan aktivitas belanja secara online, serta manfaat-manfaat lainnya yang dapat dikembangkan oleh para penyelenggara marketplace.
Aspek

kepuasan

(satisfaction)

mempengaruhi tingkat kepercayaan (trust) seseorang dalam melakukan aktivitas belanja online. Hal ini penting bagi penyelenggara marketplace untuk meningkatkan kepuasan konsumen dan meningkatkan keamanan sistem pada marketplace yang dimiliki. Kepuasan yang maksimal membuat konsumen bersedia untuk memberikan data dan informasi pribadi (seperti; nomor kartu kredit, alamat, dan nomor ponsel) kepada penyelenggara marketplace, bersedia untuk melakukan pembayaran di awal sehingga keamanan sistem dan keamanan data pribadi menjadi indikator penting yang harus dijaga kerahasiaannya. Selain itu, kualitas produk yang baik menjadi aspek kepercayaan konsumen yang menjadi dasar pemilihan konsumen untuk memilih suatu marketplace untuk berbelanja secara online. Dalam hal menjaga kualitas produk yang dijual, penyelenggara marketplace dapat melakukan pengecekan berulang dengan kriteria yang diharapkan oleh konsumen, deskripsi dari produk yang dijual juga diharapkan dapat sesuai dengan keaslian kondisi produk yang dijual pada marketplace tersebut.

Kenyaman dalam menggunakan (perceived enjoyment) juga dapat mempengaruhi niat seseorang untuk melakukan kembali aktivitas 
belanja online pada marketplace tertentu, hal ini menjadi penting bagi penyelenggara marketplace untuk menampilan konten yang menarik yaitu konten dengan warna yang sesuai, bahasa yang mudah dipahami, kualitas gambar produk yang berkualitas dan deskripsi produk yang jelas dan lengkap. Selain itu, promosi masih menjadi daya tarik sekaligus stimulus yang dapat membuat konsumen untuk melakukan pembelian kembali secara online.

\section{Rekomendasi Penelitian Selanjutnya}

Penelitian ini masih berfokus pada responden yang berada di Jakarta khususnya di kawasan urban/perkotaan, sehingga belum menunjukkan secara umum perilaku konsumen online secara keseluruhan. Untuk itu, diharapkan penelitian selanjutnya dapat dilakukan di beberapa wilayah lainnya yang berbeda sehingga dapat menemukan gambaran perilaku secara lebih luas dan dapat membandingkan perbedaan perilaku antara satu wilayah dengan wilayah lainnya.

Jumlah responden yang masih kecil dalam penelitian ini membuat hasil penelitian ini belum dapat secara utuh menggambarkan perilaku konsumen terhadap aktivitas belanja online dengan berbagai usia dan latar belakang yang berbeda-beda. Sehingga diharapkan penelitian selanjutnya dapat dilakukan dengan jumlah sampel yang lebih besar. Penelitian selanjutnya juga diharapkan dapat melakukan modifikasi model dengan menyesuikan lagi variabel-variabel yang diduga dapat menjadi variabel utama dalam konteks untuk memprediksi faktor-faktor yang mempengaruhi seseorang untuk kembali berbelanja online pada suatu marketplace. 


\section{DAFTAR PUSTAKA}

Abdul, M. A., \& Steve, L. (2012). What Drives Mobile Commerce? An Empirical Evaluation of the Revised UTAUT Model. International Journal of Management and Marketing Academy, 82-99.

Al-Qeisi, \& Ibrahim, K. (2009). Analyzing the Use of UTAUT Model in Explaining an Online Behaviour: Internet Banking Adoption. A thesis submitted for the degree of Doctor of Philosophy, $1-360$.

Al-Qeisi, K., Dennis, C., Hegazy, A., \& Abbad, M. (2015). How Viable Is the UTAUT Model in a NonWestern Context? . Canadian Center of Science and Education, 204-220.

APJII. (2017). Penetrasi dan Perilaku Penggguna Internet Indonesia (Survey 2017). Jakarta: Asosiasi Penyelenggara Jasa Internet Indonesia.

Aseanup. (2018, June 12). aseanup.com. Retrieved September 14, 2018, from aseanup Web site: https://aseanup.com/top-e-commerce-sites-indonesia/

Awuah, L. J. (2012). An Emperical Analysis of Citizens' Acceptance Decisions of ElectronicGovernment Services: A Modification of The Unified Theory of Acceptance and Use od technology (UTAUT) Model To Include Trust As A Basis For Investigation. ProQuest LLC., 1186.

Cermati.com. (2016, November 6). Cermati.com. Retrieved from Cermati.com: https://www.cermati.com/artikel/mau-pintar-bisnis-online-kenali-istilah-ini

Chao, W., Victor, R. P., \& Chenyan, X. (2011). An Integrated Model for Customer Online Repurchase Intention. Faculty Research \& Creative Activity, 1-11.

Chian, S. Y. (2012). Factors Effecting Individuals to Adopt Mobile Banking: Emperical Evidence From The UTAUT Model. Journal of Electronic Commerce Research, 104-121.

Ching-Fu, C., \& DungChun, T. (2007). How destination image and evaluative factors affect behavioral intentions? Elsevier, 1115-1122.

CNBC Indonesia. (2018, February 18). cnbcindonesia.com. Retrieved January 26, 2019, from cnbcindonesia.com: https://www.cnbcindonesia.com/lifestyle/20180218101031-33-4647/priaindonesia-lebih-suka-belanja-online-dibanding-wanita

David, G. (2000). E-Commerce: the Role of Familiarity and Trust. elsevier, 725-737.

Dewi, A. A., Hidayanto, N. A., Shihab, R. M., \& Zhu, Y.-Q. (2017). Trust Transfer and its Effects on the Continuance Usage of Mobile Service in B2C E-Marketplaces. Pacifc Asia Conference on Information Systems (PACIS), 1-17.

Dörnyei, Z. (2007). Research methods in applied linguistics. New York: Oxford University Press.

Efraim, T., David, K., Jae Kyu, L., Ting-Peng, L., \& Deborrah, C. T. (2015). Electronic Commerce. New York: Springer International Publishing Switzerland .

Erin, C.-A., \& Rajiv, K. (2006). An Extension of the UTAUT Model with E-Quality, Trust, and Satisfaction Constructs. Department of Management Science \& Systems School of Management State University of New York at Buffalo, 82-89. 
Giri, R. R., \& Saad, A. N. (2015). Implementation of Analysis Model UTAUT to Online Behavior in Adopting Internet Banking in Bandung. American Scientific Publishers, 1-7.

Ilker, E., Sulaiman, A. M., \& Rukayya, S. A. (2016). Comparison of Convenience Sampling and Purposive Sampling. American Journal of Theoretical and Applied Statistics, 1-4.

Imersmuda. (2018, April 13). imersmuda. Retrieved October 08, 2018, from imersmuda.com: http://imersmuda.com/perkembangan-e-commerce-di-indonesia/

Indrawati. (2015). Metodologi Penelitian Manajemen dan Bisnis Konvergensi Teknologi Komunikasi dan Informasi. Bandung: PT Refika Aditama.

Inside.id. (2018, May 28). Inside.id. Retrieved October 08, 2018, from Inside.id: https://inside.id/artikel/ECommerce-Tidak-Menakjubkan-Tanpa-Fasilitas-Perbankan

Iprice insight. (2018, July 31). iprice insight.co.id. Retrieved September 14, 2018, from iprice insight.co.id: https://iprice.co.id/insights/mapofecommerce/

Iprice insight. (2018, September 15). iprice.co.id. Retrieved September 15, 2018, from iprice.co.id: https://iprice.co.id/insights/stateofecommerce2017/

Jaya, I. G., \& Sumertajaya, I. M. (2008). Pemodelan Persamaan Struktural dengan Partial LeastSquare. Semnas Matematika dan Pendidikan Matematika , 118-132.

Jeffrey, F. R., \& Jaworski, B. J. (2001). e-commerce. SIngapore: McGraw-Hill Higer Education.

John, E. A., \& Paul, H. S. (2004). SME Adoption of Wireless LAN Technology: Applying the UTAUT Model. Proceedings of the 7th Annual Conference of the Southern Association for Information Systems, 39-43.

Joseph, F. J., Rolph, E. A., Ronald, L. T., \& William, C. B. (1995). Multivariate Data Analysis. United States of America: Prentice-Hall, Inc.

Katadata. (2018, February 12). databoks.katadata. Retrieved September 13, 13, from katadata.co.id: https://databoks.katadata.co.id/datapublish/2018/02/12/2022-penjualan-e-commerce-indonesiamencapai-rp-16-miliar

Kenneth, C., \& Carol, G. T. (2011). E-Commerce 2011, 7th edition. England: Pearson.

Liputan6. (2017, May 20). Liputan 6. Retrieved September 13, 2018, from Liputan 6 Web site: https://www.liputan6.com/tekno/read/2957050/pertumbuhan-e-commerce-indonesia-tertinggi-didunia

Mckinsey. (2018, August). mckensey. Retrieved August 14, 2018, from mckensey.com: https://www.mckinsey.com/featured-insights/asia-pacific/the-digital-archipelago-how-onlinecommerce-is-driving-indonesias-economic-development

Milad, K. (2012). The Effect of Electronic Word of Mouth, Trust and Perceived Value on Behavioral Intention from the Perspective of Consumers. International Journal of Academic Research in Economics and Management Sciences, 1-11.

MIN, Q., Ji, S., \& Qu, F. (2008). Mobile Commerce User Acceptance Study in China: A Revised UTAUT Model. Tsinghua Science and Technology, 257-264. 
Norizan, K. (2010). The Effect of Perceived Service Quality Dimensions on Customer Satisfaction, Trust, and Loyalty in E-Commerce Settings. Emerald Insight, 351-371.

Rakhi, T., \& Mala, S. (2014). Adoption readiness, personal innovativeness, perceived risk and usage intention across customer groups for mobile payment services in India. Emerald Insight, 369-392.

Saebani, \& Nurjaman, A. B. (2013). Manajemen Penelitian. Bandung: CV Pustaka Setia.

Samuel, A., \& Hilla, A. (2014). Review of Studies with UTAUT as Conceptual Framework. European Scientific Journal, 249-258.

Sedarmayanti, \& Hidayat, S. (2011). Metodologi Penelitian. Bandung: CV Mandar Maju.

Selim, Aren, M., Guzel, E., Kabadayi, L., \& Alpkan. (2013). Factors Affecting Repurchase Intention to Shop at the Same Website. Elsevier, 536-544.

Singgih, S. (2012). Analisis SEM Menggunakan AMOS. Jakarta: PT. Gramedia.

Sugiyono. (2011). Metode Penelitian Kombinasi. Bandung: Alfabeta.

Suha, A., \& Anne, M. (2008). The Use of the UTAUT Model in the Adoption of E-government Services in Kuwait. Proceedings of the 41st Hawaii International Conference on System Sciences, 1-11.

Taiwo, A. A., \& Downe, A. G. (2013). The Theory of User Acceptance and Use of Technology (UTAUT): A Meta-Analytic Review of Empirical Findings. Journal of Theoretical and Applied Information Technology, 48-58.

Techinasia. (2018, July 2). techinasia. Retrieved October 8, 2018, from techinasia: https://id.techinasia.com/tren-belanja-online-indonesia-ramadan

Tiago, O., \& Matilde, A. (2017). Modelling and Testing Consumer Trust Dimensions in E-Commerce. Elsevier, 153-164.

Tribun News. (2018, January 30). Tribun News. Retrieved November 18, 2018, from Tribun News Web site: http://www.tribunnews.com/techno/2018/01/30/rata-rata-orang-indonesia-keluarkan-duit-rp481-ribu-saat-belanja-online

Turban, E., Lee, J. K., Turban, D. C., King, D., \& Liang, T. P. (2015). Electronic Commerce. New York: Springer.

Ulum, M., Tirta, I. M., \& Anggraeni, D. (2014). Analisis structural equation modeling (SEM) untuk sampel kecil dengan pendekatan partial least square (PLS). Prosiding Seminar Nasional Matematika, Universitas Jember, 1-15.

Viswanath, V., James, Y. L., \& Frank, K. Y. (2011). Extending the Two-Stage Information Systems Continuance Model: Incorporating UTAUT Predictors and the Role of Context. Information Systems Journal, 527-555.

Viswanath, V., Michael, G. M., \& Gordon, B. D. (2003). User Acceptance of Information Technology: Toward a Unified View. MIS Quarterly, 425-478.

Viswanath, V., Thong, J. Y., \& Xu, X. (2012). Consumer Acceptance Use of Information Technology: Extenting The Unified Theory of Acceptance And Use of Technology. MIS Quarterly, 157-178. 
Yulia, W. S., \& Kim, D. J. (2018). Assessing the Effects of Consumers' Product Evaluations and Trust on Repurchase Intention in E-Commerce Environments. Elsevier, 199-219.

Yulin, F., Israr, Q., Heshan, S., Patrick, M., Elaine, R., \& Kai, H. L. (2014). Trust, Satisfaction, and Online Repurchase Intention: The Moderating Role of Perceived Effectiveness of E-Commerce Institutional Mechanisms. MIS Quarterly, 402-427.

Zahir, M., \& Gharleghi, B. (2015). Adoption of Internet Banking in Maldives, the Most Important Determinants. Canadian Center of Science and Education, 181-189. 